\title{
Effects of selective logging on tree species diversity and composition of Bornean tropical rain forests at different spatial scales
}

\section{AUTHOR(S):}

Imai, Nobuo; Seino, Tatsuyuki; Aiba, Shin-ichiro; Takyu, Masaaki; Titin, Jupiri; Kitayama, Kanehiro

\section{CITATION:}

Imai, Nobuo ... [et al]. Effects of selective logging on tree species diversity and composition of Bornean tropical rain forests at different spatial scales. Plant Ecology 2012, 213(9): 1413-1424

\section{ISSUE DATE:}

2012-09

URL:

http://hdl.handle.net/2433/160099

\section{RIGHT:}

The final publication is available at www.springerlink.com; This is not the published version. Please cite only the published version.; この論文 は出版社版でありません。引用の際には出版社版をご確認ご利用くだ さい。 
1 Authors: Nobuo Imai ${ }^{1 *}$, Tatsuyuki Seino ${ }^{2}$, Shin-ichiro Aiba ${ }^{3}$, Masaaki Takyu ${ }^{4}$,

2 Jupiri Titin ${ }^{5}$, Kanehiro Kitayama ${ }^{1}$

3

4

Title: Effects of selective logging on tree species diversity and composition of Bornean tropical rain forests at different spatial scales

\section{Affiliations:}

${ }^{1}$ Graduate School of Agriculture, Kyoto University, Oiwake-cho, Kitashirakawa, Sakyo-ku, Kyoto 606-8502, Japan

${ }^{2}$ Graduate School of Life and Environmental Sciences, University of Tsukuba, Tennodai, Tsukuba, Ibaraki 305-8577, Japan

${ }^{3}$ Graduate School of Science and Engineering, Kagoshima University, Korimoto, Kagoshima 890-0065, Japan

${ }^{4}$ Faculty of Regional Environmental Science, Tokyo University of Agriculture, Sakuragaoka, Setagaya-ku, Tokyo 156-8502, Japan

${ }^{5}$ Forest Research Centre, Sabah Forestry Department, 90715 Sandakan, Sabah, P.O.Box 1407, Malaysia

\section{* Corresponding author:}

Email: inobuo@kais.kyoto-u.ac.jp

Tel\&fax: +81-75-753-6080 
Abstract Reduced-impact logging (RIL) is known to be beneficial in biodiversity conservation, but its effects on tree diversity remain unknown. Pattern of tree diversity following disturbance usually varies with spatial scale of sampling (i.e. plot size). We examined the impacts of RIL on species richness and community composition of tree species at different spatial scales, and the scale (plot size) dependency of the two metrics; species richness vs. community similarity. One 2 -ha and three to four 0.2 -ha plots were established in each of primary, RIL and conventionally logged (CL) forest in Sabah, Malaysia. Species richness (the number of species per unit number of stems) was higher in the RIL than in the CL forest at both scales. The relationship between species richness and logging intensity varied with plot size. Species richness was greater in the RIL than in the primary forest at the 2-ha scale, while it was similar between the two forests at 0.2 -ha scale. Similarly, species richness in the CL forest demonstrated a greater value at the 2-ha scale than at the 0.2 -ha scale. Greater species richness in the two logged forests at the 2 -ha scale is attributable to a greater probability of encountering the species-rich, small patches that are distributed heterogeneously. Community composition of the RIL forest more resembled that of the primary forest than that of the CL forest, regardless of plot size. Accordingly, species richness is a scale-dependent metric, while community similarity is a more robust metric to indicate the response of tree assemblage to anthropogenic disturbance.

Keywords Borneo; forest heterogeneity; non-metric multi-dimensional scaling (NMDS); PERMANOVA; species-accumulation curves 


\section{Introduction}

Forests degraded due to anthropogenic disturbances are rapidly expanding in area in the tropics (Asner et al. 2005; Wright 2005). Degraded tropical forests usually have higher species richness than monocultural plantations and agricultural lands (Gibson et al. 2011, Lawton et al. 1998). On the other hand, strictly protected areas that are expected to conserve biodiversity are rather limited in area (Rodrigues et al. 2004), leading to a growing interest in the conservation value of degraded tropical forests (Berry et al. 2010, Edwards et al. 2010). A key driver of forest degradation in Southeast Asian tropics is unregulated selective logging, which often damages more than $50 \%$ of the original forest biomass, and causes surface-soil disturbance (Bertault and Sist 1997; Cannon et al. 1994; Pinard and Putz 1996; Putz et al. 2008a; Sist et al. 1998). Understanding the responses of biodiversity to selective logging in the tropics is crucial for predicting and managing biodiversity in our rapidly changing global environment.

To mitigate the detrimental impacts of selective logging on forests, "reduced-impact logging" (RIL) has recently been applied to some of natural production forests in the tropics (Kleine and Heuveldop 1993; Lagan et al. 2007; Putz et al. 2008a). RIL is a modification of selective logging, including pre-harvest inventory, mapping of all canopy trees, directional felling, liana cutting and planning of skid trails, log decks and roads. In comparison with unregulated conventional logging (CL), RIL is beneficial not only in maintaining future crop trees (Peña-Claros et al. 2008; Rockwell et al. 2007) and forest biomass (Bertault and Sist 1997; Johns et al. 1996; Miller et al. 2011; Pinard and Putz 1996; Putz et al. 2008b; Sist et al. 1998), 
but also in biological diversity, such as dung beetles (Davis 2000), flying insects (Akutsu et al. 2007), soil macrofauna (Hasegawa et al. 2006) and forest-dwelling vertebrates (Imai et al. 2009). Many other taxa, such as ants, arachnids, bats, birds, fishes and animals, also are not adversely affected by RIL (Azevedo-Ramos et al. 2006; Bicknell and Peres 2010; Castro-Arellano et al. 2007; Dias et al. 2010; Edwards et al. 2012; Felton et al. 2008; Presley et al. 2008; Samejima et al. 2012; Wunderle et al. 2006). However, the effects of RIL on tree species diversity of tropical rain forests remain largely unknown, despite that the diversity of trees is fundamental to the structure and functions of the forests. The diversity of trees may also determine the diversity of other taxonomic groups, because trees provide resources and habitat structure for dependent species.

To date, only three studies have examined the effects of RIL on tree species diversity (Foody and Cutler 2003; Medjibe et al. 2011; Webb and Peralta 1998). However, two studies compared tree diversity of RIL with that of primary forest (Medjibe et al. 2011; Webb and Peralta 1998), and only one study compared tree diversity of RIL with that of both primary and CL forest by using quite a small (0.05 ha in area) plot (Foody and Cutler 2003). Given that widespread commercial logging of high-value timber in the tropics still rely mainly upon conventional techniques (Blaser et al. 2011), comparison of logging impacts on tree diversity between RIL and CL is urgently needed.

Tree species richness (number of tree species at a single site) in selectively logged forests may vary depending on the spatial scale of sampling (Dumbrell et al. 2008; Hamer and Hill 2000; Hill and Hamer 
101

102

103

104

105

106

107

108

109

110

111

112

113

114

115

116

117

118

119

120

121

2004). Selectively logged forests consist of a mosaic of patches affected by different intensities of disturbance, such as remnant stands, gaps due to harvesting and road construction, and regenerating patches with varying successional stages. A small plot can encounter only one or a few patch types within a heterogeneous logged-over forest. On the other hand, a large plot is potentially able to encounter all different patch types within the forest. Because logging creates new habitats for the species not found in a primary forest, deploying a large plot overestimates species richness in a logged-over forest. Accordingly, plot size, which determines the number of different patch types encountered in a given area, can in turn affect species richness in that area. However, previous studies assessing tree species richness in selectively logged forests have used either small (mostly less than 0.2 ha in area) or large plots ( 1 ha in area in a few studies; Berry et al. 2008; Chua et al. 1998; Kirika et al. 2010; Medjibe et al. 2011; Ouédraogo et al. 2011, Souza et al. 2012). Deploying both small and large plots is necessary to reliable evaluation of logging impacts on tree species richness. The ideal metric of biodiversity must be independent of spatial scale of sampling (Chazdon et al. 1998). Sheil and Burslem (2003) reported that tree species richness in tropical forests following habitat disturbance varied with spatial scale. On the other hand, community similarity (difference of community composition between sites) is receiving increasing attention as a useful metric to assess the effects of forest managements on biodiversity, rather than species richness (Barlow et al. 2007; Su et al. 2004). Despite that, no assessment of the scale-dependent response of tree community similarity to habitat disturbance has yet been conducted. Understanding the 
scale dependency of the two major metrics following disturbance can improve the interpretation of the outcome of tropical biodiversity studies, in which sampling size and evaluation metrics largely differ among different studies.

We established one 2-ha and three to four 0.2-ha plots in each of primary, RIL and CL forest in Bornean lowland tropical rain forests to examine the effects of RIL on tree species richness and composition at different spatial scales. We also compared the scale (plot size) dependency of the two metrics (species richness vs. community similarity) to consider which metric is more appropriate for evaluation of the forest-management effects on tropical biodiversity.

\section{Material and methods}

Study site

This study was carried out in Deramakot Forest Reserve and Tangkulap Forest Reserve in Sabah, Malaysia ( $\left.5^{\circ} 14-30^{\prime} \mathrm{N}, 117^{\circ} 11-36^{\prime} \mathrm{E}\right)$. The mean annual temperature of the area is $27^{\circ} \mathrm{C}$ and the mean annual precipitation is c. 3500 $\mathrm{mm}$, with little seasonal variation. The region is characterized by Tertiary sedimentary rocks. The altitude in the reserves is between 20 and $300 \mathrm{~m}$ asl. The vegetation is a mixed dipterocarp lowland tropical rain forest. Deramakot $\left(551 \mathrm{~km}^{2}\right)$ and Tangkulap $\left(275 \mathrm{~km}^{2}\right)$ are located adjacent to each other. Deramakot and Tangkulap were originally licensed for logging starting in 1956 and the 1970s, respectively. Subsequently, conventional logging commenced there (Sabah Forestry Department 2005). During 1959-1968, timber, with a mean volume of $109 \mathrm{~m}^{3} /$ ha, was harvested in 
151 Deramakot (Sabah Forestry Department 2005). In 1989, Deramakot was

152 chosen by the Sabah State Government as a model site to develop a

153 sustainable forest management system and all logging activities were

154 suspended thereafter. A new management system with RIL was implemented

155 in 1995. Deramakot is now divided into 135 compartments of varying sizes

156 (approx. 500 ha each), and about two to four compartments are harvested

157 annually using RIL with a planned rotation period of $40 \mathrm{yr}$ (Lagan et al. 2007).

15817 of these compartments $(3,473$ ha in area) are reserved for conservation

159 (not to produce $\log s$ ).

160 Based on the guidelines of RIL, all harvestable trees must be measured

161 before harvesting and located on a detailed map and appropriate routes for

162 skidders are designed to minimize the damage to non-target trees. The trees

163 harvested are limited to those in the range of 60-120 cm diameter at breast

164 height (dbh), and trees that are near streams, on steep terrain, with hollows,

165 or of fruiting species for wildlife are excluded from harvesting. A

166 compartment will be harvested only when the harvestable timbers exceed 25

$167 \mathrm{~m}^{3} /$ ha. Tangling lianas are cut before harvesting and targeted trees are

168 harvested with a directional felling technique. Harvesting and road

169 construction cease during periods of heavy rainfall to reduce soil erosion.

170 Gap size of each harvesting must be less than 0.1 ha. Dipterocarpaceae is one

171 of the major targeted tree families for harvesting. In Deramakot, a total of

17224,934 trees $\left(2.36\right.$ trees /ha) with a volume of $145,399 \mathrm{~m}^{3}\left(13.74 \mathrm{~m}^{3} / \mathrm{ha}\right)$ were

173 harvested during 1995-2006 (Samejima et al. 2012).

Tangkulap Forest Reserve was repeatedly logged using a conventional

175 logging technique until 2001, when the government suspended all logging 
176

177

178

179

180

181

182

183

184

185

186

187

188

189

190

191

192

193

194

195

196

197

198

199

200

activities. There are no reliable statistics for the log production in Tangkulap. According to the analysis of logging history in the two reserves using Landsat satellite data (Imai et al. 2009), much heavier logging have occurred in greater areas in Tangkulap compared with Deramakot during 1985-2002. This difference of degradation status between Deramakot and Tangkulap resulted from the differences of the two logging methods (i.e. RIL and CL) and harvested volume between the two reserves. We used these forests as a model site to examine the impacts of RIL on species richness and community composition of tree species at different spatial scales, and the scale (plot size) dependency of the two metrics; species richness vs. community similarity.

\section{Vegetation survey}

Eleven research plots of 0.2 ha were established in Deramakot and Tangkulap during May 2003-March 2005 (Seino et al. 2006). In Deramakot, four plots were established in a primary forest located within the conservation area. Conventional logging method has been applied even in the current conservation area until the 1980 s, and there are still evidences of the past logging activities (e.g. old bulldozer paths, old stumps, and absence of emergent trees) in the vicinity of our plots. However, we considered our four plots are in unlogged patches of primary forest, because of the absence of any evidence of past logging activities within the plots. In Deramakot, we also set up four plots in the forest logged by RIL during 1995-2000. In Tangkulap, three plots logged by CL were established. The three CL plots were once logged before 1988, and again logged during 1995-1999, based on the observation of Landsat scenes (Aoyagi R. pers. comm.). Thus, the two logged 
201 forests were logged during the similar period; RIL and CL forest were logged

202

203

204

205

206

207 5-13 and 5-10 yr before our investigation, respectively. Eleven 0.2-ha plots were laid out primarily as $100 \times 20 \mathrm{~m}$. Three out of the four plots in primary forest and one out of the three plots in CL forest were laid out as $50 \times 40 \mathrm{~m}$, because of the limited availability of gentle topography. Mean $( \pm$ SD) distances among the 0.2 -ha plots are $435 \pm 209,1130 \pm 646$ and $756 \pm 175 \mathrm{~m}$ for primary, RIL and CL forest, respectively. During November 2006-February 2008, we enlarged one representative 0.2 -ha RIL plot and one representative 0.2 -ha CL plot to 2 ha in area $(200 \times 100 \mathrm{~m})$. We additionally established a new 2-ha plot in primary forest, because the four 0.2 -ha primary plots are in small patches of residual forest and therefore cannot be enlarged without including degraded patches. Each plot consists of $10 \times 10-\mathrm{m}$ subplots. All trees $\geq 10 \mathrm{~cm} \mathrm{dbh}$ were measured in each plot. We also established a hundred $5 \times 5$-m plots within a 2 -ha plot (allocated alternately to each $10 \times 10-\mathrm{m}$ subplot), and measured dbh of small trees with $5-10 \mathrm{~cm}$ dbh. Buttressed trees were measured at well above $(c .50 \mathrm{~cm})$ protrusions. All trees were identified by botanical experts of the Herbarium, Forest Research Centre, Sabah Forestry Department, Sandakan. Voucher specimens were collected from the trees that could not be identified in situ. Specimens taken were compared with herbarium collections. Samples that could not be identified to species were distinguished as morphospecies.

Plot shape may affect tree species richness, because a rectangular plot may sample a greater number of species than a square plot of the same area (Condit et al. 1996). However, when we tested the effects of plot shape $(100 \times 20 \mathrm{~m}$ vs. $50 \times 40 \mathrm{~m})$ using subplots within a 2 -ha plot, the mean 
number of tree species $\geq 10 \mathrm{~cm}$ dbh did not significantly differ between ten $100 \times 20-\mathrm{m}$ subplots and ten $50 \times 40-\mathrm{m}$ subplots (Student's $t$-test, $P>0.5$ for all, only 1.1-1.9 species greater in $100 \times 20-\mathrm{m}$ subplots). This is probably because the aspect ratio of our study plots was relatively low \{only from $1.25(50 \times 40 \mathrm{~m})$ to $5(100 \times 20 \mathrm{~m})\}$. We therefore suggest that the use of different plot shapes does not affect tree species richness in our study.

\section{Data analysis}

Above-ground biomass

Above-ground biomass (AGB) was estimated according to the allometric equation obtained by Chave et al. (2005) as:

$$
\mathrm{AGB}=\rho \times \exp \left(-1.499+2.148 \ln (D)+0.207(\ln (D))^{2}-0.0281(\ln (D))^{3}\right)
$$

where $D$ is $\mathrm{dbh}(\mathrm{cm})$ and $\rho$ is the wood-specific gravity $\left(\mathrm{g} / \mathrm{cm}^{3}\right)$. We obtained the wood-specific gravity $\rho$ for the observed species/genera from various sources (Lemmens et al. 1995; Oey 1951; Soerianegara and Lemmens 1993; Sosef et al. 1998). In cases, where a range of wood density values were reported, we used a median value. Where wood density data were unavailable for a species, the average across all species in that genus was applied (see Baker et al. 2004; Slik 2006). In the few cases, where trees could not be identified at the genus level or where no literature record was available, we used the mean wood specific gravity of that plot.

\section{Forest heterogeneity}

To evaluate the forest heterogeneity within a 2-ha plot in each forest type, 
we calculated a commonly-used measure of $\beta$-diversity (Whittaker 1960) within a 2-ha plot:

$$
\beta=\gamma / \alpha
$$

We calculated the number of species at the scale of $40 \times 50 \mathrm{~m}$ within each of the 2 -ha plots (i.e. ten 0.2 -ha subplots by sequentially shifting $40 \times 50$-m quadrat per 2 -ha plot), and obtained $\beta$ by dividing the total number of species in each 2 -ha plot $(\gamma)$ by the mean number of species per 0.2 -ha subplots $(\alpha)$.

\section{Community similarity}

We tested the differences in tree community composition among forest types using ordinations and permutational multivariate analysis of variance (PERMANOVA; Anderson 2001). The Chao dissimilarity (distance) function and the relative basal area of each species in eleven 0.2 -ha plots $(n$ $=11)$ and three 2 -ha plots separated at the scale of $40 \times 50 \mathrm{~m}$ within each of the 2 -ha plots $(n=30)$ were used to calculate the distance matrix. The PERMANOVA used the "adonis" procedure in the vegan package in R. Ordinations were plotted with non-metric multidimensional scaling (NMDS) using the vegan's "metaMDS" procedure.

\section{Species richness}

We estimated the number of tree species by using rarefaction, which is used to calculate the number of species expected in a subsample selected at random from a total sample (Gotelli and Colwell 2001; Magurran 2004). We ran 100 randomizations using the data of the number of trees $\geq 10 \mathrm{~cm} \mathrm{dbh}$ for 
each species at $10 \times 10$-m subplots by EstimateS ver. 8 (available online at http://viceroy.eeb.uconn.edu/estimates) to produce species-area curves. The species-individual curves were obtained by converting the cumulative area to cumulative numbers of individuals. Estimated number of species for 70 stems in the 0.2 -ha plots and for 850 stems in the 2 -ha plots were separately calculated by interpolation from the species-individual curves; 70 and 850 were the number of individuals in the site with the smallest total number of individuals at each plot size.

Differences in vegetation properties (stem density, basal area, AGB, observed and estimated number of species) among forest types were tested by an analysis of variance (ANOVA). When the ANOVA $P$ value was $<0.05$, the Tukey-Kramer post hoc test was performed to determine which pairs of means differ significantly.

\section{Scale dependency of the two metrics}

To examine the scale dependency of the two metrics, we tested which metrics (species richness and community similarity) better correlated with AGB at both 0.2-ha and 2-ha scales. Estimated AGB in each plot was considered as a surrogate of the degree of forest degradation. Estimated number of species in each plot was used as an index of species richness, because it can compare expected species richness between data of different sample sizes (Gotelli and Colwell 2001; Magurran 2004). NMDS axis 1 score in each plot was used as an index of community similarity.

Unfortunately, we established only one 2 -ha plot per forest type due to impenetrability in our study site. However, the lack of replicates is not 
critical in this analysis because we applied a linear model.

\section{RESULTS}

\section{Forest structure}

Stem density in 0.2 -ha plots tended to be lower in CL than in the other two forests $(P<0.1)$, but did not differ between primary and RIL forest (Table 1). Stem density in 2-ha plots decreased with increasing logging intensity (Table 1). Densities of trees $\geq 60 \mathrm{~cm} \mathrm{dbh}$ in 0.2 -ha plots and trees with 5-10 cm dbh in 2-ha plots were lower in CL than in the other two forests (Fig. 1, $P<0.05$ for both).

In 0.2-ha plots, $\mathrm{AGB}$, maximum dbh and total basal area were lower in CL than in the other two forests, but did not differ between primary and RIL forest (Table 1). These structural properties showed a similar pattern also in 2-ha plots to that shown in 0.2 -ha plots.

\section{Community similarity and forest heterogeneity}

Dipterocarp species dominate primary and RIL forest, while pioneer species (mostly Macaranga spp.) were abundant in CL forest (Table 1). Community composition consistently differed between CL and the other two forests at both 0.2 -ha (PERMANOVA, $P<0.05)$ and 2 -ha scales $(P<0.001)$ (Table 2 ). While community composition of RIL forest also differed from that of primary forest at 2 -ha scale $(P<0.001)$, it did not differ from that of primary forest at 0.2 -ha scale $(P>0.05)$. Primary and CL forest were plotted at the opposite extremes along the NMDS axis 1 consistently at both scales (Fig. 2a,b). RIL forest was plotted at similar positions with primary 
forest at 0.2-ha scale (Fig. 2a) while at an intermediate position at 2-ha scale (Fig. 2b).

Forest heterogeneity within a 2-ha plot, measured with Whittaker's $\beta$-diversity, increased with increasing logging intensity $(4.1,4.6$ and 4.8 in primary, RIL and CL forest, respectively).

\section{Species richness}

We recorded 1324 stems of 360 species in 0.2 -ha plots and 2992 stems of 544 species ( 3614 stems $\geq 5 \mathrm{~cm}$ dbh of 589 species) in 2 -ha plots. Observed number of families and genera were lower in CL than in the other two forests in 0.2-ha plots, while it did not largely differ among forest types in 2-ha plots (Table 1). Observed number of species per unit area was lower in CL than in the other two forests, but did not differ between primary and RIL forest, regardless of plot size and tree size class (Table 1, Fig. 3a-c,g-j). Species richness (estimated number of species) in 0.2 -ha plots was also lower in CL than in the other two forests (Table 1). Species richness in 2-ha plots was greater in RIL, intermediate in primary, and lower in CL forest. Species richness of primary forest was 1.6 times greater at 0.2 -ha scale (50.1 vs. 31.1 species), while only 1.06 times greater at 2 -ha scale than that of CL forest (257 vs. 243 species). Such higher species richness of the two logged forests at 2-ha scale compared at 0.2 -ha scale is due to the difference in species richness of small trees between 0.2 -ha and 2-ha scale. In 2-ha plots, species richness of trees with 5-20 cm dbh did not differ between primary and $\mathrm{CV}$ forest (Fig. 3m,n), and that with 10-20 $\mathrm{cm}$ dbh was rather higher in RIL than in primary forest (Fig. $3 \mathrm{~m}$ ). 
351 Scale dependency of the two metrics

352 A significant relationship between species richness and AGB (as the degree 353 of forest degradation) was obtained at only one out of the three plot designs 354 (i.e. replicated 0.2-ha plots) (Fig. 4a). By contrast, there was a consistent 355 linear relationship between NMDS axis 1 scores (as community similarity) 356 and AGB irrespective of plot design (Fig. 4d-f).

\section{DISCUSSION}

359 Species richness in RIL forest was consistently higher than that in CL forest 360 at both spatial scales, and rather higher than that in primary forest at 2 -ha 361 scale. Conventional logging in Tangkulap has caused a greater disturbance, 362 which have led to the loss of late-successional species. Logging following 363 the RIL guidelines in Deramakot extracted a reduced volume of timber and 364 reduced collateral damages to the residual stands (Lagan et al. 2007). Such 365 efforts may create favorable habitats for pioneer species, while maintain the 366 late-successional species, leading to the greater species richness in RIL than 367 in the other two forests. This may correspond with the intermediate 368 disturbance hypothesis (Connell 1978), which predicts local species 369 diversity to be maximal at an intermediate level of disturbance, due to the 370 coexistence of late-successional and pioneer species. Accordingly, RIL does 371 not appear to reduce tree species richness substantially, nor does it promote 372 the prolific colonization of pioneer species. Relationships between tree species richness and logging intensity 374 varied with plot size. There was no difference in species richness between 375 primary and RIL forest at 0.2 -ha scale, but rather higher richness in RIL 
than in primary forest at 2 -ha scale. Species richness of primary forest was 1.6 times greater at 0.2 -ha scale, but only 1.06 times greater at 2 -ha scale than that of CL forest. Logged forests consist of both patches with low species richness (due to the degradation or the dominance of a few pioneer species recruited) and patches with relatively high species richness (due to the coexistence of late-successional and pioneer species at small size class). In degraded forest landscapes, the latter patches may occupy a small area and be distributed heterogeneously. Probability of encountering such patches with high species richness will decrease when sampled with smaller plots. This is one major reason why the two logged forests showed relatively higher species richness at 2-ha scale compared at 0.2 -ha scale. Previous studies have demonstrated inconsistent responses of tree species richness to selective logging, with unchanged (Bischoff et al. 2005; Foody and Cutler 2003; Hall et al. 2003; Kirika et al. 2010; Medjibe et al. 2011; Slik et al. 2002; Verburg and van Eijk-Bos 2003), decreased (Brearley et al. 2004; Gutiérrez-Granados et al. 2011; Makana and Thomas 2006; Okuda et al. 2003), and increased (Berry et al. 2010; Cannon et al. 1998; Plumptre 1996) richness following logging. Most studies used a single plot size, and compared species richness between unlogged and logged forests without the variation of logging intensity (but see Kirika et al. 2010; Molino and Sabatier 2001; Verburg and van Eijk-Bos 2003). Selective logging actually has a wide variation in the volume of timber extracted and the severity of damage caused by the removal of individual trees and road construction (Cannon et al. 1994). Our results indicate that responses of tree species richness to logging intensity can covary with plot size. These 
401

402

403

404

405

406

407

408

409

410

411

412

413

414

415

416

417

418

419

420

421

422

two uncontrolled factors (logging intensity and plot size) among different studies may be the possible reasons for the inconsistent responses of tree species richness to selective logging.

Unlike species richness, community composition of RIL forest more resembled that of primary forest than that of CL forest regardless of plot size. Therefore, community similarity consistently showed a linear relationship with the degree of forest degradation irrespective of plot design (Fig. 4). Community similarity is a sensitive and consistent metric to evaluate the effects of logging on tree assemblage, rather than species richness per se, which inevitably combines the responses of two contrasting regeneration guilds (pioneer and late-successional species), provides no information on such species identity, and is highly dependent on spatial scale of sampling.

In conclusion, RIL can conserve the richness and community composition of tree species at a similar level with primary forest. These positive effects are a co-benefit of RIL, because RIL is primarily a forestry practice to sustainably produce timber. Unfortunately, unregulated selective logging is still common in the tropics (Blaser et al. 2011). If RIL were adopted in much larger areas of natural production forests, a substantial reduction of logging damage on tree assemblage can be expected while timber is sustainably produced. Our results also demonstrated different scale-dependent responses between the two metrics (species richness and community similarity) to logging intensity. We suggest that research on the forest-management adequacy should include several metrics including community similarity at different spatial scales, rather than just evaluating 
426 changes in a single metric relating to species richness at a single spatial 427 scale.

\section{Acknowledgements}

430 This work was supported by the Global Environment Research Fund F-071 431 and D-1006 of the Ministry of the Environment, Japan, to KK. We thank 432 D.K.M. Esther for assisting research plot establishment, M. Poster and D. 433 Joel for tree species identification, R. Ajon and many other persons for 434 assisting field survey, R. Aoyagi, A. Langner and A. Tanaka for remote 435 sensing analysis, P. Lagan for generous support for every aspect. We 436 acknowledge the kind assistance from Sabah Forestry Department and 437 Forest Research Centre, Sabah.

\section{References}

440 Akutsu K, Khen CV, Toda MJ (2007) Assessment of higher insect taxa as 441 bioindicators for different logging-disturbance regimes in lowland 442 tropical rain forest in Sabah, Malaysia. Ecol Res 22:542-550 Anderson MJ (2001) A new method for non-parametric multivariate analysis of variance. Austral Ecol 26:32-46

Asner GP, Knapp DE, Broadbent EN et al (2005) Selective logging in the Brazilian Amazon. Science 310:480-482

Azevedo-Ramos C, De Carvalho Jr O, Do Amaral BD (2006) Short-term effects of reduced-impact logging on eastern Amazon fauna. For Ecol Manage 232:2635

450 Baker TR, Phillips OL, Malhi Y et al (2004) Variation in wood density 
determines spatial patterns in Amazonian forest biomass. Global Chang Biol 10:545-562

Barlow J, Gardner TA, Araujo IS et al (2007) Quantifying the biodiversity value of tropical primary, secondary, and plantation forests. Proc Natl Acad Sci USA 104:18555-18560

Berry NJ, Phillips OL, Lewis SL et al (2010) The high value of logged tropical forests: lessons from northern Borneo. Biodiversity Conserv 19:985-997

Berry NJ, Phillips OL, Ong RC et al (2008) Impacts of selective logging on tree diversity across a rainforest landscape: the importance of spatial scale. Landscape Ecol 23:915-929

Bertault JG, Sist P (1997) An experimental comparison of different harvesting intensities with reduced-impact and conventional logging in East Kalimantan, Indonesia. For Ecol Manage 94:209-218

Bicknell J, Peres CA (2010) Vertebrate population responses to reduced-impact logging in a neotropical forest. For Ecol Manage 259:2267-2275

Bischoff W, Newbery DM, Lingenfelder M et al (2005) Secondary succession and dipterocarp recruitment in Bornean rain forest after logging. For Ecol Manage 218:174-192

Blaser J, Sarre A, Poore D et al (2011) Status of tropical forest management. ITTO Technical Series 38. International Tropical Timber Organization, Yokohama, Japan

Brearley FQ, Prajadinata S, Kidd PS et al (2004) Structure and floristics of an old secondary rain forest in Central Kalimantan, Indonesia, and a 
comparison with adjacent primary forest. For Ecol Manage 195:385-397

Cannon CH, Peart DR, Leighton M et al (1994) The structure of lowland rainforest after selective logging in West Kalimantan, Indonesia. For Ecol Manage 67:49-68

Cannon CH, Peart DR, Leighton M (1998) Tree species diversity in commercially logged Bornean rainforest. Science 281:1366-1368

Castro-Arellano I, Presley SJ, Saldanha LN et al (2007) Effects of reduced impact logging on bat biodiversity in terra firme forest of lowland Amazonia. Biol Conserv 138:269-285

Chave J, Andalo C, Brown S et al (2005) Tree allometry and improved estimation of carbon stocks and balance in tropical forests. Oecologia 145:87-99

Chazdon RL, Colwell RK, Denslow JS et al (1998) Statistical methods for estimating species richness of woody regeneration in primary and secondary rain forests of Northeastern Costa Rica. In: Dallmeier F, Comiskey JA (eds) Forest biodiversity research, monitoring and modeling: conceptual background and old world case studies. Parthenon Publishing, Paris, pp 285-309

Chua LSL, Hawthorne WD, Guan SL et al (1998) Biodiversity database and assessment of logging impacts. In: Lee SS, Dan YM, Gauld ID et al (eds) Conservation, management and development of forest resources. Forest Research Institute Malaysia, Kuala Lumpur, pp 30-40

Condit R, Hubbell SP, Lafrankie JV et al (1996) Species-area and species-individual relationships for tropical trees: a comparison of three 50-ha plots. J Ecol 84:549-562 
501 Connell JH (1978). Diversity in tropical rain forests and coral reefs.

$502 \quad$ Science 199:1302-1310

503 Davis AJ (2000) Does reduced-impact logging help preserve biodiversity in 504 tropical rainforests? A case study from Borneo using dung beetles 505 (Coleoptera: Scarabaeoidea) as indicators. Environ Entomol 29:467-475 506 Dias MS, Magnusson WE, Zuanon J (2010) Effects of reduced-impact $507 \quad$ logging on fish assemblages in central Amazonia. Conserv Biol $508 \quad 24: 278-286$

509 Dumbrell AJ, Clark EJ, Frost GA et al (2008) Changes in species diversity 510 following habitat disturbance are dependent on spatial scale: theoretical 511 and empirical evidence. J Appl Ecol 45:1531-1539

512 Edwards DP, Larsen TH, Docherty TDS et al (2010) Degraded lands worth 513 protecting: the biological importance of Southeast Asia's repeatedly 514 logged forests. Proc R Soc B-Biol Sci 278:82-90

518 Felton A, Wood J, Felton AM et al (2008) Bird community responses to 519 reduced-impact logging in a certified forestry concession in lowland $520 \quad$ Bolivia. Biol Conserv 141:545-555

521 Foody GM, Cutler MEJ (2003) Tree biodiversity in protected and logged 522 Bornean tropical rain forests and its measurement by satellite remote 523 sensing. J Biogeography 30:1053-1066

524 Gibson L, Lee TM, Koh LP et al. (2011) Primary forests are irreplaceable 525 for sustaining tropical biodiversity. Nature 478:378-381 
526 Gotelli NJ, Colwell RK (2001) Quantifying biodiversity: procedures and pitfalls in the measurement and comparison of species richness. Ecol Lett

Gutiérrez-Granados G, Pérez-Salicrup DR, Dirzo R (2011) Differential diameter-size effects of forest management on tree species richness and community structure: implications for conservation. Biodivers Conserv 20:1571-1585

Hall JS, Harris DJ, Medjibe V et al (2003) The effects of selective logging on forest structure and tree species composition in a Central African forest: implications for management of conservation areas. For Ecol Manage 183:249-264

Hamer KC, Hill JK (2000) Scale-dependent effects of habitat disturbance on species richness in tropical forests. Conserv Biol 14:1435-1440

Hasegawa M, Ito MT, Kitayama K et al (2006) Logging effects on soil macrofauna in the rainforests of Deramakot Forest Reserve, Sabah, Malaysia. In: Lee YF, Chung AYC, Kitayama K (eds) Proceedings of the $2^{\text {nd }}$ workshop on synergy between carbon management and biodiversity conservation in tropical rain forests. Forest Research Centre, Forestry Department, Sabah, pp 53-60

Hill JK, Hamer KC (2004) Determining impacts of habitat modification on diversity of tropical forest fauna: the importance of spatial scale. J Appl

\section{Ecol 41:744-754}

Imai N, Samejima H, Langner A et al (2009) Co-benefits of sustainable forest management in biodiversity conservation and carbon sequestration. PLoS One 4:e8267 
551 Johns JS, Barreto P, Uhl C (1996) Logging damage during planned and

552 unplanned logging operations in the eastern Amazon. For Ecol Manage $553 \quad 89: 59-77$

554 Kirika JM, Bhning-Gaese K, Dumbo B et al (2010) Reduced abundance of 555 late-successional trees but not of seedlings in heavily compared with 556 lightly logged sites of three East African tropical forests. J Trop Ecol $26: 533-546$

Kleine M, Heuveldop J (1993) A management of planning concept for sustained yield of tropical forests in Sabah, Malaysia. For Ecol Manage 61:277-297

Lagan P, Mannan S, Matsubayashi H (2007) Sustainable use of tropical forests by reduced-impact logging in Deramakot Forest Reserve, Sabah, Malaysia. Ecol Res 22:414-421

Lawton JH, Bignell DE, Bolton B et al (1998) Biodiversity inventories, indicator taxa and effects of habitat modification in tropical forest. Nature 391:72-76

Lemmens RHMJ, Soerianegara I, Wong WC (1995) Timber trees: minor commercial timbers, Plant Resources South-east Asia 5(2). Backhuys Publishers, Leiden, pp 655

Magurran AE (2004) Measuring biological diversity. Blackwell Science Ltd, Oxford, pp 256

Makana JR, Thomas SC (2006) Impacts of selective logging and agricultural clearing on forest structure, floristic composition and diversity, and timber tree regeneration in the Ituri Forest, Democratic Republic of Congo. Biodivers Conserv 15:1375-1397 
Medjibe VP, Putz FE, Starkey MP et al (2011) Impacts of selective logging on above-ground forest biomass in the Monts de Cristal in Gabon. For Ecol Manage 262:1806-1799

Miller SD, Goulden ML, Hutyra LR et al (2011) Reduced impact logging minimally alters tropical rainforest carbon and energy exchange. Proc Natl Acad Sci USA 108:19431-19435

Molino JF, Sabatier D (2001) Tree diversity in tropical rain forests: a validation of the intermediate disturbance hypothesis. Science 294:1702-1704

Oey DS (1951) Perbandingan berat dari djenis 2 kaju Indonesia dan pengartian beratnja kaju untunk keperluan praktek. Penjelidikan Kehutanan, Bogor, pp 183

Okuda T, Suzuki M, Adachi N et al (2003) Effect of selective logging on canopy and stand structure and tree species composition in a lowland dipterocarp forest in peninsular Malaysia. For Ecol Manage 175:297-320

Ouédraogo DY, Beina D, Picard N et al (2011) Thinning after selective logging facilitates floristic composition recovery in a tropical rain forest of Central Africa. For Ecol Manage 262: 2176-2186

Peña-Claros M, Fredericksen TS, Alarcón A et al (2008) Beyond reduced-impact logging: silvicultural treatments to increase growth rates of tropical trees. For Ecol Manage 256:1458-1467

Pinard MA, Putz FE (1996) Retaining forest biomass by reducing logging damage. Biotropica 28:278-295

Plumptre AJ (1996) Changes following 60 years of selective timber harvesting in the Budongo Forest Reserve, Uganda. For Ecol Manage 
89:101-113

602

603

604

605

606

607

608

609

610

611

612

613

614

615

616

617

618

619

620

Presley SJ, Willig MR, Wunderle Jr JM et al (2008) Effects of reduced-impact logging and forest physiognomy on bat populations of lowland Amazonian forest. J Appl Ecol 45:14-25

Putz FE, Sist P, Fredericksen T et al (2008a) Reduced-impact logging: challenges and opportunities. For Ecol Manage 256:1427-1433

Putz FE, Zuidema PA, Pinard MA et al (2008b) Improved tropical forest management for carbon retention. PLoS Biol 6:e166

Rockwell CA, Kainer KA, Staudhammer CL et al (2007) Future crop tree damage in a certified community forest in southwestern Amazonia. For Ecol Manage 242:108-118

Rodrigues ASL, Andelman SJ, Bakan MI et al (2004) Effectiveness of the global protected area network in representing species diversity. Nature 428:640-643

Sabah Forestry Department (2005) Forest management plant 2: Deramakot Forest Reserve, Forest management unit no.19. Sandakan

Samejima H, Ong R, Lagan P et al (2012) Camera-trapping rates of mammals and birds in a Bornean tropical rainforest under sustainable forest management. For Ecol Manage 270:248-256

Seino T, Takyu M, Aiba SI et al (2006) Floristic composition, stand structure, and above-ground biomass of the tropical rain forests of Deramakot and Tangkulap Forest Reserve in Malaysia under different forest managements. In: Lee YF, Chung AYC, Kitayama K (eds) Proceedings of the $2^{\text {nd }}$ workshop on synergy between carbon management and biodiversity conservation in tropical rain forests. Forest Research 
Sheil D, Burslem DFRP (2003) Disturbing hypotheses in tropical forests.

Sist P, Nolan T, Bertault JG et al (1998) Harvesting intensity versus sustainability in Indonesia. For Ecol Manage 108:251-260

Slik JWF (2006) Estimating species-specific wood density from the genus average in Indonesian trees. J Trop Ecol 22:481-482

Slik JWF, Verburg RW, Keßler PJA (2002) Effects of fire and selective logging on the tree species composition of lowland dipterocarp forest in East Kalimantan, Indonesia. Biodivers Conserv 11:85-98

Soerianegara I, Lemmens RHMJ (1993) Timber trees: major commercial timbers, Plant Resources South-east Asia 5(1). Backhuys Publishers, Leiden, pp 605

Sosef MSM, Hong LT, Prawirohatmodjo S (1998) Timber trees: lesser-known timbers, Plant Resources South-east Asia 5(3). Backhuys Publishers, Leiden, pp 859

Souza AF, Cortez LSR, Longhi SJ (2012) Native forest management in subtropical South America: long-term effects of logging and multiple-use on forest structure and diversity. Biodivers Cons 21:1953-1969

Su JC, Debinski DM, Jakubauskas ME et al (2004) Beyond species richness: community similarity as a measure of cross-taxon congruence for coarse-filter conservation. Conserv Biol 18:167-173

Verburg R, Van Eijk-Bos C (2003) Effects of selective logging on tree diversity, composition and plant functional type patterns in a Bornean rain forest. J Veg Sci 14:99-110 
651 Webb EL, Peralta R (1998) Tree community diversity of lowland swamp 652 forest in Northeast Costa Rica, and changes associated with controlled 653 selective logging. Biodivers Conserv 7:565-583

654 Whittaker RH (1960) Vegetation of the Siskiyou Mountains, Oregon and 655 California. Ecol Monogr 30:279-338

656 Wright SJ (2005) Tropical forests in a changing environment. Trends Ecol $657 \quad$ Evol 20:553-560

658 Wunderle Jr JM, Henriques LMP, Willig MR (2006) Short-term responses of 659 birds to forest gaps and understory: an assessment of reduced-impact $660 \quad$ logging in a lowland Amazon forest. Biotropica 38:235-255

661

662

663

664

665

666

667

668

669

670

671

672

673

674

675 
676 Table 1 Forest structure and tree species diversity of three to four 0.2-ha

677 plots and one 2-ha plot in primary, reduced-impact logged (RIL), and

678 conventionally logged (CL) forest. Stem density, above-ground biomass

679 (AGB), maximum dbh, basal area, observed number of families, genera

680 and species, and estimated number species (per 70 stems in 0.2 -ha plots

681 and per 850 stems in 2 -ha plots) are shown. Parentheses indicate values

682 for trees $\geq 5 \mathrm{~cm} \mathrm{dbh}$. Forests sharing the same letters do not differ

683 significantly at $P<0.05$. Pioneer species: five Macaranga species $(M$.

684 conifera, M. gigantea, M. hypoleuca, M. pearsonii, M. bancana) and two

685 Croton species ( $C$. argyratus, C. oblongus) of Euphorbiaceae, and two

686 Rubiaceae species (Neolamarckia cadamba, Neonauclea sp.)

\begin{tabular}{|c|c|c|c|c|c|c|c|c|c|c|c|c|}
\hline \multirow[b]{3}{*}{ Stem density (/ha) } & \multicolumn{6}{|c|}{0.2 -ha plots } & \multicolumn{6}{|c|}{ 2-ha plots } \\
\hline & \multicolumn{2}{|c|}{ Primary } & \multicolumn{2}{|c|}{ RIL } & \multicolumn{2}{|c|}{ CL } & \multicolumn{2}{|c|}{ Primary } & \multicolumn{2}{|c|}{ RIL } & \multicolumn{2}{|c|}{$\mathrm{CL}$} \\
\hline & 623 & \pm 97 & 613 & \pm 72 & 457 & \pm 85 & 607 & & 504 & & 428 & \\
\hline AGB $(\mathrm{Mg} / \mathrm{ha})$ & $499^{\mathrm{a}}$ & \pm 60 & $341^{\mathrm{a}}$ & \pm 52 & $163^{\mathrm{b}}$ & \pm 84 & 378 & & 290 & & 216 & \\
\hline Maximum dbh (cm) & $114^{\mathrm{a}}$ & \pm 12 & $106^{\mathrm{a}}$ & \pm 10 & $63^{b}$ & \pm 9 & 129 & & 145 & & 92 & \\
\hline \multicolumn{13}{|l|}{ Basal area $\left(\mathrm{m}^{2} / \mathrm{ha}\right)$} \\
\hline Total & $41.2^{\mathrm{a}}$ & \pm 4.6 & $32.7^{\mathrm{a}}$ & \pm 4.5 & $19.0^{\mathrm{b}}$ & \pm 7.4 & 34.2 & & 28.6 & & 23.3 & \\
\hline Dipterocarp & $19.9^{\mathrm{a}}$ & \pm 3.7 & $13.2^{\mathrm{b}}$ & \pm 3.4 & $5.1^{\mathrm{c}}$ & \pm 0.8 & 17.6 & & 12.4 & & 8.5 & \\
\hline Pioneer & $1.3^{\mathrm{b}}$ & \pm 0.5 & $2.3^{\mathrm{b}}$ & \pm 1.9 & $8.1^{\mathrm{a}}$ & \pm 3.7 & 0.4 & & 2.4 & & 4.2 & \\
\hline Observed no. families & $30.3^{a}$ & \pm 1.9 & $29.0^{\mathrm{a}}$ & \pm 2.0 & $20.7^{\mathrm{b}}$ & \pm 2.1 & 52 & $(52)$ & 51 & (53) & 48 & $(51)$ \\
\hline Observed no. genera & $51.5^{\mathrm{a}}$ & \pm 5.4 & $51.5^{\mathrm{a}}$ & \pm 4.5 & $30.0^{\mathrm{b}}$ & \pm 4.6 & 135 & $(144)$ & 124 & $(134)$ & 121 & (131) \\
\hline Observed no. species & $82.5^{a}$ & \pm 9.3 & $79.5^{\mathrm{a}}$ & \pm 10.3 & $39.3^{\mathrm{b}}$ & \pm 6.4 & 296 & (319) & 298 & $(340)$ & 243 & $(263)$ \\
\hline Estimated no. species & $50.1^{\mathrm{a}}$ & \pm 9.1 & $49.5^{\mathrm{a}}$ & \pm 5.9 & $31.1^{\mathrm{b}}$ & \pm 6.3 & 257 & & 282 & & 243 & \\
\hline
\end{tabular}


688 Table 2 PERMANOVA test results for community-composition

689 differences between primary, reduced-impact logged (RIL) and

690 conventionally logged (CL) forest. The $r^{2}$ values are shown for all

691 pairwise comparisons between forest types. Significant differences are in

692 bold. $P=*<0.05, * *<0.01, * * *<0.001$

693

\begin{tabular}{lrc}
\hline & 0.2 -ha plots & 2-ha plots \\
\hline Among the three forests & $\mathbf{0 . 1 9}{ }^{* *}$ & $\mathbf{0 . 3 5}{ }^{* * *}$ \\
Primary-RIL & 0.15 & $\mathbf{0 . 3 1}$ \\
Primary-CL & $\mathbf{0 . 3 1}$ & $\mathbf{0 . 3 9}$ \\
RIL-CL & $\mathbf{0 . 3 6}$ & $\mathbf{0 . 1 8}$ \\
\hline
\end{tabular}

694

695

696

697

698

699

700

701

702

703

704

705

706 
708

709

710

711

712

713

\section{Figure captions}

Fig. 1 Frequency distribution of $\mathrm{dbh}$ for trees $\geq 5 \mathrm{~cm} \mathrm{dbh}$ at one 2-ha plot (black bars) and trees $\geq 10 \mathrm{~cm} \mathrm{dbh}$ at three to four 0.2 -ha plots (dotted bars) in primary (a), reduced-impact logged (RIL) (b) and conventionally logged (CL) forest (c). Values for trees $\geq 60 \mathrm{~cm} \mathrm{dbh}$ are also shown in an inlet. Error bars indicate SD.

Fig. 2 An ordination of tree community composition of primary, reduced-impact logged (RIL) and conventionally logged (CL) forest in the eleven 0.2 -ha plots (a) and thirty 0.2 -ha subplots in the three 2 -ha plots (b) on the coordinate of axis 1 and axis 2 of NMDS analysis. Stress values are also shown.

Fig. 3 Species accumulation curves of three to four 0.2 -ha plots (a-f) and one 2-ha plot (g-n) in each of primary, reduced-impact logged (RIL) and conventionally logged (CL) forest by tree size class. Error bars indicate SD. Species-area curves: a-c,g-j; species-individual curves: $d-f, k-n$

Fig. 4 Relationships between above-ground biomass (AGB) and estimated number of species (a-c) and NMDS axis 1 scores $(d-f)$ in the three sampling designs; three to four 0.2 -ha plots and a 2 -ha plot in primary, reduced-impact logged (RIL) and conventionally logged (CL) forest, and ten 0.2 -ha subplots within each 2 -ha plot. Relationships significant at $P<$ 0.05 only are shown. 


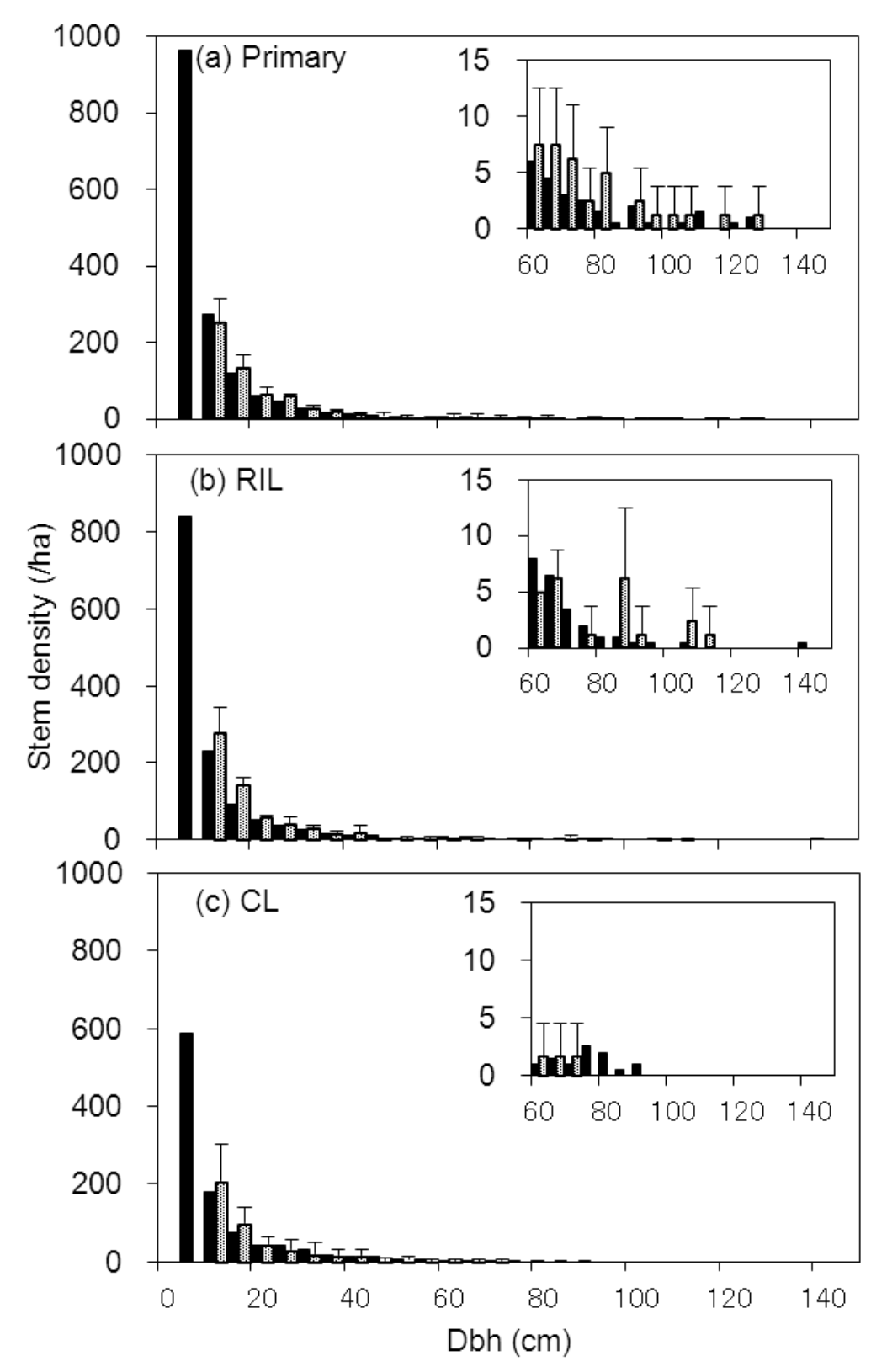



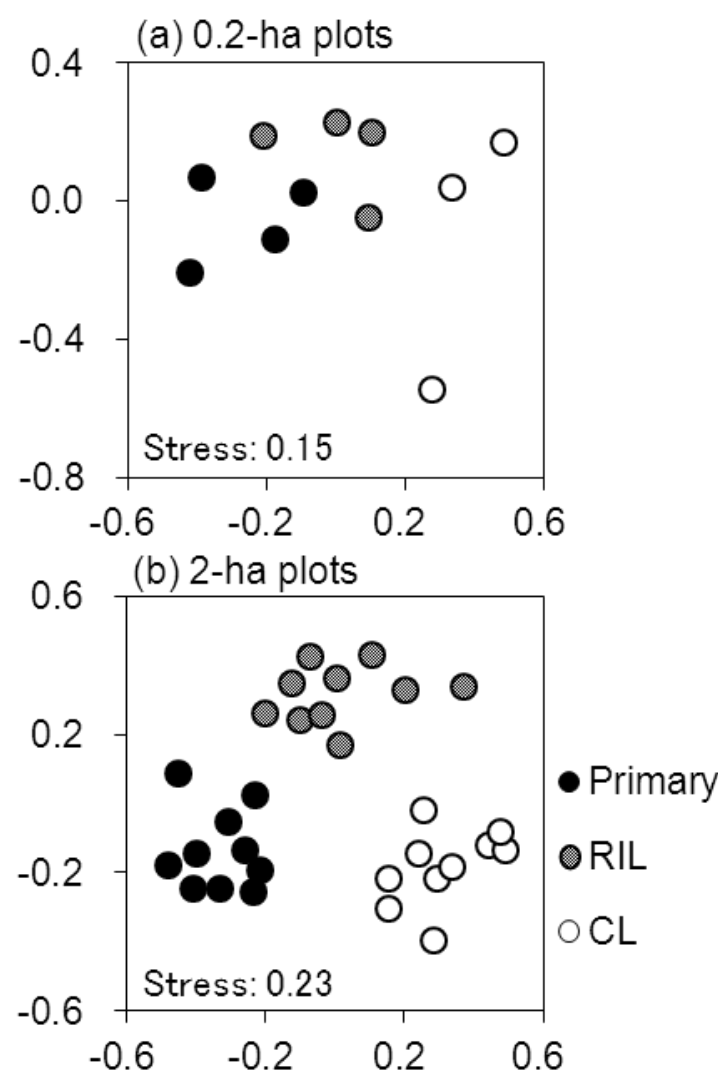

738

739 Fig. 2

740 
0.2-ha plots

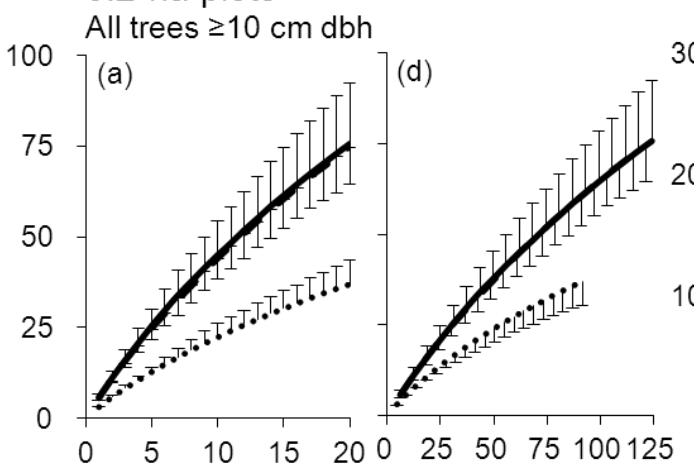

All trees $\geq 20 \mathrm{~cm} \mathrm{dbh}$

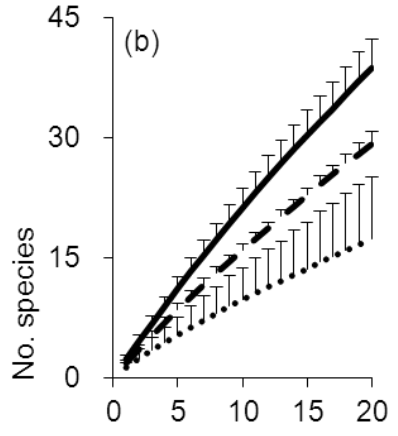

$7(e)$

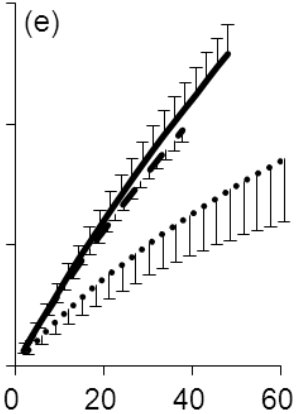

70
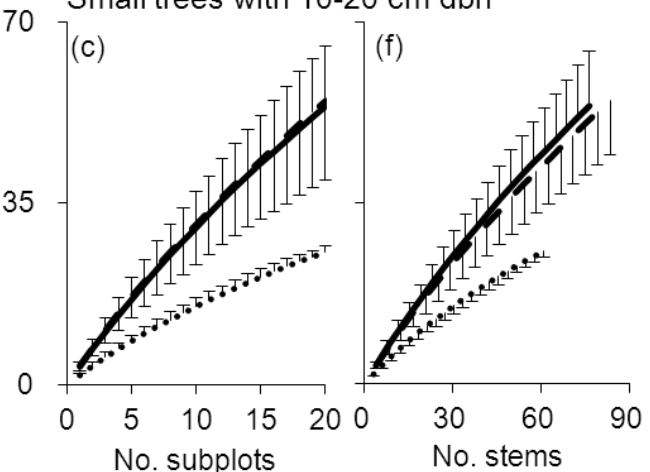

180 All trees $\geq 10 \mathrm{~cm} \mathrm{dbh}$

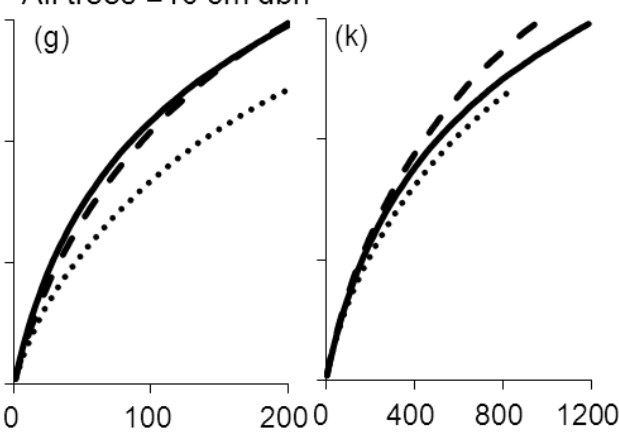

All trees $\geq 20 \mathrm{~cm} \mathrm{dbh}$

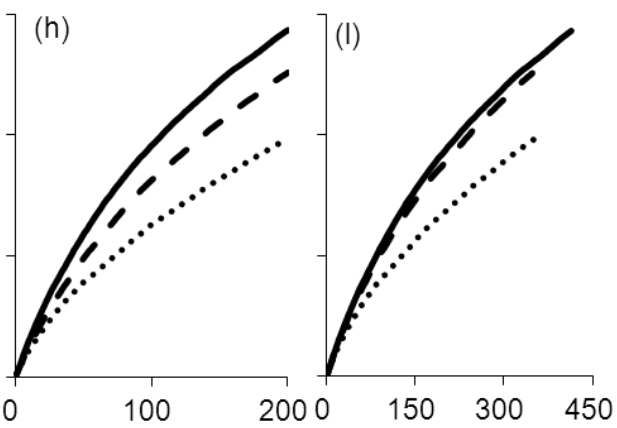

250 Small trees with $10-20 \mathrm{~cm} \mathrm{dbh}$
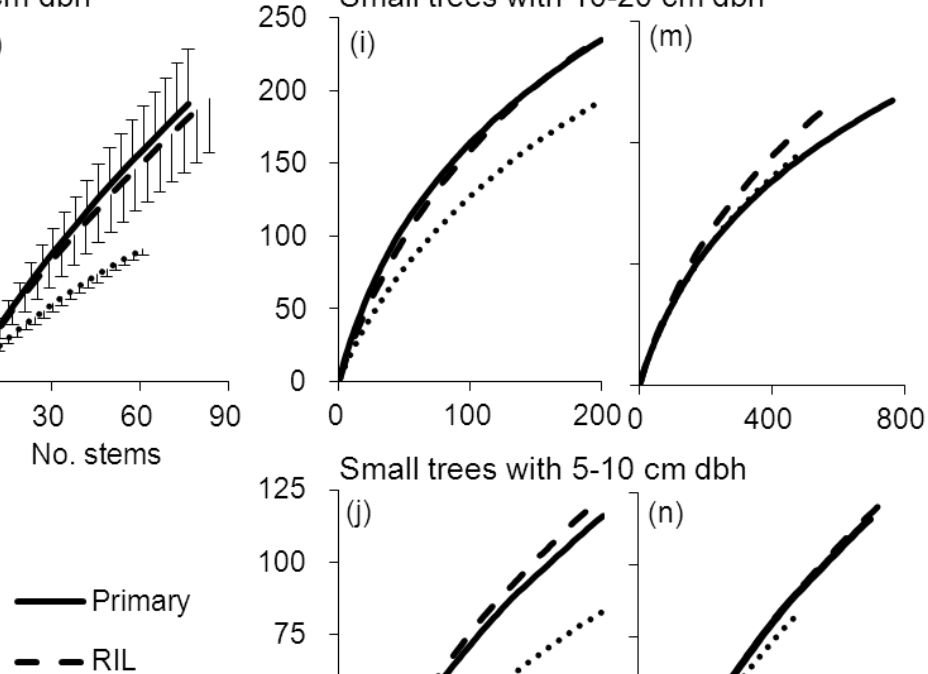

...... CL

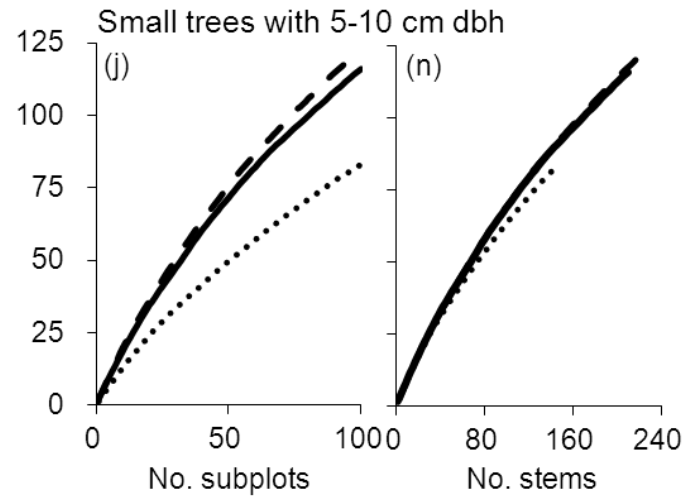

Fig. 3 


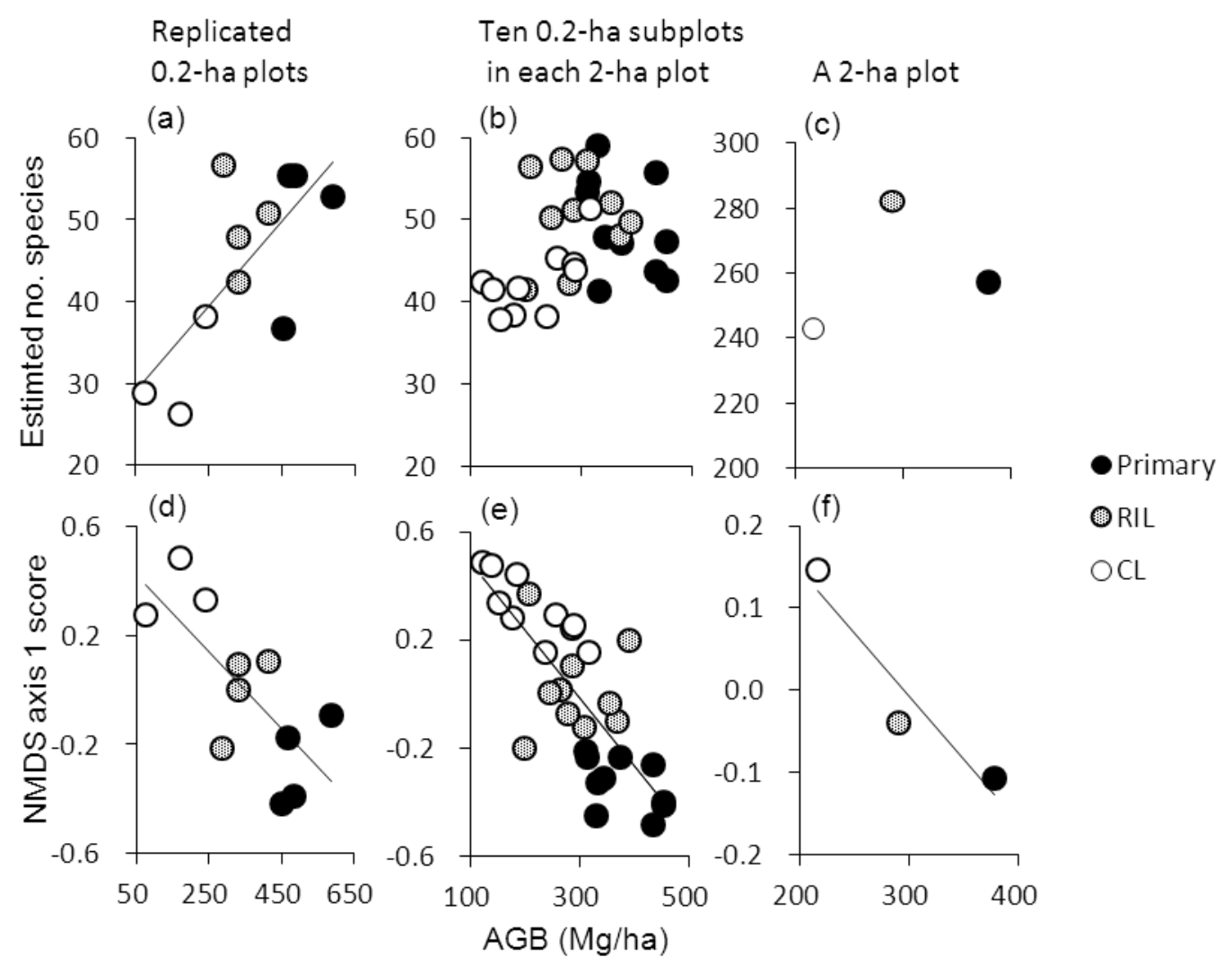

745

746

747 Fig. 4 